\title{
Political Islam's relation to Capital and Class
}

\section{Ardeshir Mehrdad and Yassamine Mather}

The last three decades have witnessed a relentless growth of Islamic movements, so that, today political Islam is an undeniable reality on the world scene. The events of September 11, 2001 and since have given it further prominence. From the Middle East to North Africa and South Asia, it has, in its various manifestations, become a major player that needs to be analysed both politically and theoretically. The contradictory nature of political Islam means that such analyses must deal with it not only in relation to the interests of capital, but also in relation to the challenge it poses to socialist ideas.

In many countries, the movements of political Islam raise their flag as that of 'seekers of justice' and aim their propaganda at the poorest and most deprived sections of society. They, thereby, present themselves as a rival to the forces of socialism and the left. The formulation of a strategy to respond to this challenge requires a deeper understanding of the background to, and reasons for, these developments. This article presents some preliminary theses, based on a necessarily limited and general outline of the characteristics and peculiarities of the Islamic movements.

Amidst the ravages of the wars in Afghanistan and Iraq, then, political Islam is on the rise, and its supporters portray it as the ideology of the poor and the dispossessed. They promise 'a better life' for the 'disinherited', 'less inequality', and the 'end of corruption' through the rule of 'sharia'a' (the religious state). Yet in Iran, almost twenty-six years after coming to power with similar promises, Islamic government has become synonymous with greed and corruption. Super-rich clerics and their immediate families have replaced the 'corrupt Royal court' and its entourage. The poor get poorer while the rich get richer. (Ayatollah Rafsanjani, the Islamic regime's previous president and likely to be its next president, is ranked the forty-third richest man in the world by Forbes Magazine.)

What, then, is the basis of the political economy of Islamic fundamentalism? How does it gain its supporters amongst the poor and the 'dispossessed'? What is the relation between the promises of equality in the rule of sharia'a and the real politics of Islamic governance within the world capitalist order?

From the 1970s onwards, as Islamic societies of the periphery were incorporated ever-deeper into the world market, the centre-periphery crisis in these societies entered a new and qualitatively different phase. The fluctuating, but, overall, downward trend in the price of raw materials, including - for most of the period - oil, on which these societies depend, speeded up the widening of inequality in social, economic and cultural development; the accumulation of foreign debt; and the increasing inability of such states to control and restrain the spiralling crises they have to confront.

\section{A modern phenomenon}

The 'revolutionary Islamic movement' is a contemporary phenomenon. Whatever may be the indirect or minor influences of past Islamic movements on it, it is attached by an 
umbilical cord to the form of world capitalism that has developed in the last three decades. The social roots of the 'political Islamic movements' are, essentially, the uprooted - those who, for a variety of reasons, have been waylaid on the path of socioeconomic development; and, to whom the new structures have brought nothing but bankruptcies and ruin. Despite variations in its social fabric in different circumstances, the pan-Islamist movement in all the more-or-less developed countries of the periphery (with a few exceptions) has recruited among four main layers.

First are the urban uprooted and deprived. They belong to the explosion of people with no stable relation to the expanding peripheral-capitalist system of production and distribution. These apparently 'cursed' people have in common a peasant ancestry, taking 'refuge' in the dirt and mud surrounding such cities as Cairo, Algiers, and Teheran. They are futureless, hopeless, degraded, and without identity or rights. In Islamic societies, the urban destitute form the social layer most ready to take up the Islamists' banner. They make up the main social base for the 'political Islamic movement.' They also generate its explosive power.

Second are middle layers belonging to pre-capitalist structures. Such people have been bankrupted or marginalised by the spread of capitalist structures and their fate is to struggle harder only to sink into greater poverty. They are important in helping to organise the Islamic movements, and in welding together their socially disparate supporters.

The third layer comprises sections of the merchant and industrial bourgeoisie left outside the circle of power. They find themselves in unequal competition with a bourgeoisie privileged by being close to (and reliant on) a state, the rationale of which has been to orchestrate development from above. In peripheral societies where the bourgeois state (rather than being the product of capitalist development) imposes the growth of capitalism from above - and where the relation between power and capital is turned upside down to the extent that it is easier to rely on power to make money than on wealth as a gateway to power - those layers of the bourgeoisie excluded from power can count on being permanent losers. This fate places manufacturers and merchants in the same camp as the 'wretched of the earth.' Such people not only fill the coffers of the Islamic movement, but can also, for a period, help to increase the attraction of pan-Islamism to the justice-seeking poor by setting up charities, interest-free loan accounts and other such schemes.

Fourth are intellectuals whose social standing has declined, who have lost out, altogether or at least to some degree, during the formation of the new political and civil structures. These intellectuals find their influence and privileges vanishing. They are increasingly isolated. Whether or not in priestly clothes, whether young or old, whether or not - objectively - their re-emergence would answer a structural need, they will use the religious movement to re-establish their place in society. They provide the leadership cadres of the movement, those who pack the ideological baggage and map the political strategy for the 'Islamic movement.'

\section{Anti-enlightenment}

The pan-Islamist movement, in its rebellion against the hopelessness capitalism has engendered, rests on the rejection of enlightenment. The ideologists of this rebellion have to close their eyes to the future, turn their backs on reality and take refuge in 
myths. This obscurantism, ironically, brings today's uprooted poor together, under one umbrella, with yesterday's rich. It is an Islam based on resurrecting, from a vast store of stories and myths, ideas that promise the end of misery for all those on the scrapheap. It insists there is no alternative to a movement that is foreign to common sense and free thought in all its forms. It treats as enemies all who favour scientific thought and who question the so-called 'certainties' (tashkik). In this view any attempt at enlightenment, whether of yesterday or today, is a devilish plot to be fought at all costs.

\section{Against class-based line-ups}

The pan-Islamist movement is a furnace in which class line-ups must melt. The non-homogeneous (multi-class) mix in the Islamists' camp dictates a policy of denying class war, or at least marginalising it and removing it from the immediate agenda. Such a non-class-based social bloc, based on religious cultural unity, has no other way of surmounting the class antagonisms within it between the hungry and those with full bellies. Here and there, 'the war between poverty and wealth' becomes a weapon for the movement to browbeat its merchant fellow-travellers when they become restless, or to loosen their purse strings. But in general, sharia'a remains firmly on the side of 'unity' and those who 'split' (monafegh) are worse than those who do not 'believe' (moshrek). It has an uncompromising enmity towards communism or any other political creed which defines society by its class boundaries and perceives class confrontations as inevitable.

\section{No national boundaries}

At every level the new 'Islamic movement' is the rising of those who not only see themselves as alienated within their own national boundaries, but also of those who have (they think) discovered the source of their destitution and bankruptcy outside these boundaries. From their beginnings, therefore, these movements face outwards. The foreign enemy is seen as the root cause of all evil; in creating the mechanisms of depravity and misery, it ensures that all Muslims suffer injustice equally.

'Political Islam', accordingly, cannot confine itself within national boundaries. To aspire to set up anything less than a world Islamic power, based on a world Islamic will, would be to acknowledge ultimate defeat. This is the logic behind the rejection of the legitimacy of all the civil and secular systems that sustain nation states, and of all international treaties and agreements between nation states. It is the context that explains the inherent contradiction involved in simultaneously opposing both imperialism and world 'arrogance', and also nationalism. The Islamic movement may here and there support tendencies aiming at independence and even isolationism. Yet it is emphatic in its rejection of nationalisms that counterpose the nation against the umma (Islamic community).

\section{Anti-democratic}

The pan-Islamist movement - however its elements interpret 'political Islam' - opposes democracy in all its forms. The movement's beliefs, class make-up and historic direction come together to reject popular sovereignty and the right of the people to determine their own destiny by majority vote. It is forced to locate the right of sovereignty above the heads of ordinary people, to make it the overarching authority 
that must resolve the movement's internal and external contradictions. Divine rule, where all rights belong to god, is the only realm where there are no tensions and dissent. And it is only the divine that can give away this or that right on earth to the chosen people - whether the Islamists in question wear clerical or civilian apparel.

Who is invested with this divine gift? This is a matter the 'chosen' must settle amongst themselves. The right of people to vote on a one-person-one-vote basis can, at best, only be accepted once. This is in regard to the initial decision - for or against the Islamic Republic. Thereafter, the only political function of the people is to express their allegiance (beia'a) to the chosen (nokhbegan).

Democracy is an institutional mechanism to establish a legal basis for government. Islam, however, recognises only particular personages - a governor, vali or caliph: it does not recognize institutions of government. Yet, in practice, it must institutionalise the right to make decisions by a small coterie of nokhbegan and religious authorities (mujtahed) - i.e. those who have the ability and 'knowledge' to interpret divine law for any given circumstance. Recognition of those who have this ability is also in the hands of those who have proven their 'knowledge' beforehand. Thus the question -"who decides?" - comes full circle.

\section{Citizen rights}

Even outside the question of political power and of government, the pan-Islamist movement cannot accept any rights for its citizens. And, even if we put aside the fact that Islamic sharia'a considers women as half a man (a destiny considered entirely compatible with 'justice'), women will do little better in the utopia that the Islamic movement is advocating. The sanctity of the family is basic to the reconstruction of this 'paradise lost', and the values cementing it together require an unambiguous definition of a woman - one that begins with her as a wife and ends with her as a mother.

Outside the Islamic framework lies the world of corruption. No matter how much political Islam shouts about human rights and the miracle of womanhood, it cannot acknowledge values which cross the boundary into this world. Sometimes this or that religion may be favoured for political purposes, so that its adherents may be afforded a status equivalent to Muslims. But for the most part non-muslims are second-class citizens or worse. Those who belong to proscribed religions, such as the Baha'i, are directed to repent or die. If today religious apartheid is put on the shelf, tomorrow the conscience of a powerful and dominant Islam will not rest until the non-Muslims find their 'rightful' position. If non-Muslims are today exempt from paying the religious tax (jezzieh), they will only have this added to future debts.

In sum, the sovereignty of the people is a concept alien to the pan-Islamism movement, which, most ominously, will actively seek to destroy it altogether.

\section{Jihad and terrorism}

The pan-Islamism movement is a 'Jihad.' The uprooted who decide that a 'wheel that does not turn for their needs should never turn', and who do not see any reason to decry the ruination of today if it leads to the utopia of tomorrow, can have no other recourse but to the sword. No open and free environment, no democratic system, no 
legal testament can guarantee their goal. Even if pan-Islamism can, in some circumstances, gain power through legal means; whether or not it is suppressed or allowed to grow; whatever its place in a particular balance of power: it has in general entered an arena of war where pulling the trigger is a daily duty. Recourse to terrorism in all its forms; the semi-military organisation of that part of the social base that can be mobilised; the creation of professional military institutions; attempts to infiltrate and recruit in the armies of Islamic countries: these are all acts which cannot be stopped or even delayed. Jihad is a road which will take pan-Islamism to the promised land.

The growing crisis and the steady weakening of governments increased the intervention of global capital in the internal affairs of Islamic countries. This process reached a point at which the finance and economic ministries of many Islamic countries turned into impotent operatives for the decision-making centres of global capital. They bowed to major and crisis-provoking restructuring of the socio-political life of their countries. They presided over policies that caused massive unemployment and attendant despair; chronic inflation ravaging meagre savings; acute housing shortages leading to running battles between the guardians of the city and the neverending waves of migrants; and non-existent healthcare facilities that transform hospitals effectively into morgues.

The savage demands of the International Monetary Fund and the credit limitations imposed by the World Bank, forced peripheral governments to turn on their own people. What little remained of state largesse, in the form of subsidies, dried up. Millions were made destitute, unprotected against misery, famine and disease. These were the people who carried Egyptian, Tunisian, Moroccan and Algerian pan-Islamism on their shoulders. The scholars of Islam would do better - and would save their institutions (official and unofficial) much money - if, instead of looking for the footprints of political Islam in history, they would wend their way to the archives of the IMF and its financial networks. There they would find the directives that cast light on the cause of the plight of their people.

\section{Crisis of political hegemony}

The centre-periphery crisis of capitalism is the prerequisite for unrest and mass uprisings in Islamic societies. But that general crisis cannot of itself direct the revolt organically in a particular way, whether towards pan-Islamism or, perhaps, progress and socialism. Without a particular set of circumstances in the political and ideological sphere, and in the arena of class conflict and social relations, pan-Islamism would not have been able to grow into a broad mass movement. An understanding of the distinctive features of those circumstances involves analysis of a particular crisis of political hegemony within the framework of a general crisis of ideology. To begin from basics, this would necessitate a rounded discussion of the particular way politicoideological structures in peripheral societies grow. This is beyond the scope of the argument here, but a few reminders may be useful.

First, although in the majority of societies under discussion the capitalist mode of production dominates, the bourgeoisie has not fully developed as the hegemonic class. The immaturity of the bourgeoisie in these social formations shows itself best in its anaemic political and ideological personality. For this reason, the dominant ideology, the prime requirement of which is the securing of the voluntary assent of the masses to 
the existing social order, at best contains only elements of bourgeois thinking. It is made up of an amalgam of nationalism, religious dogma, elements of petit-bourgeois ideas, paternalistic and tribal values, along with some aspects of liberalism.

Second, the acceleration of structural changes very quickly upsets the class-political line-ups and in uniquely new divisions and allegiances. The ruling ideological amalgam, discussed above, is not only incapable of fulfilling the task of gaining the assent of the masses, but also loses its effectiveness even within the ruling bloc. Not surprisingly, therefore, any attempt to remodel and renew this doctrine has the effect of reducing further its influence on one section of society just as it appears to increase its capacity to influence other sectors. In other words, the more it becomes aware of the need to update its ideology, the more the bourgeosie both loses its ability to universalize its essential ideology and, paradoxically, provokes confrontations amongst the subordinate ideological trends.

Third, the end result of such a process, especially if it coincides with a major collapse of the government's economic programmes, appears in the form of multi-dimensional changes in the various political structures. Inside the ruling bloc the crisis surfaces as one of hegemony, which not only causes a series of changes in the balance of power, but also often leads the purging of - or even a bloody suppression of - some of the ruling factions. This, in turn, reduces more than ever the hegemonic political influence of the ruling bloc on the masses, diminishing its social base even further.

But at the opposite pole, the working class is powerless not only because of its relative youth and political immaturity but also because it lacks an effective ideological base. The 'Marxism-Leninism' packaged in the 'Academies of Science' of the 'socialist bloc', in conjunction with various theories of the 'non-capitalist road to socialism', in no way served to unite the working class. Quite the opposite. These theories rationalized the splitting of the political and trade-union movement into small groupings, and the collapse of other sections of workers into passivity or open surrender. In some countries the communist and worker parties went as far as liquidating themselves and amalgamating with the ruling party (e.g. in Egypt). In others, there was an inexorable process distancing the mass of workers from worker-based political organisations.

To complete the picture, there was systematic police repression. Taken together, all this explains why, at a time when conditions for the growth of the class pole opposing the bourgeoisie were at their best, the working class remained weaker and more helpless than ever. This catastrophic balance between the two main class poles in society promoted not so much political paralysis as a vacuum - both of political representation and of legitimacy. In such situations the voice from the minarets gains an ear. A multicoloured amalgam of social layers is attracted by the invitation to a jihad, apparently taking its ideology from ancient tales and sayings, but actually resurrected on the ruins, chaos and wretchedness of today.

\section{Facilitating factors}

We have argued, then that the current conjuncture of political and economic crises 
provides the necessary pre-conditions for the mass pan-Islamist movement in peripheral Islamic societies. But this is not the full explanation for the explosive growth of this phenomenon. To understand how pan-Islamism is a credible government-in-waiting in a number of counties, and indeed, has taken over power in some, we must consider a number of facilitating factors:

First is the presence of an official religious establishment with a network of mosques and schools; an abundance of paid cadres; firm roots, to some extent independent of state power; the ability to be in direct daily contact with people; and finally certain legal and political immunities, and numerous social and legal privileges. Whatever control is exerted on the official religious establishment, it remains the main ideological arsenal and the durable political background of pan-Islamism.

Second, we must consider the ruling political administrations' attitude to religion. In most Islamic countries, despite the gradual separation between the state and the religious structures - and all the ups and downs in the relations between them - some form of working alliance has always been maintained. The prime purpose of this has been to oppose the left and the workers' movement. At every juncture where the workers and democratic movement have made advances, threatening the despotic and authoritarian systems, the religious apparatus has joined the army and police as an arm of repression. In return, from time to time, the state has acted to spread the network of religious schools and mosques; to facilitate the establishment of workplace and neighbourhood Islamic societies; and to promote the religious establishment's political influence by means of cultural, devotional, and charitable organisations. Finally - in conditions of a single-party state - there has been toleration of the quasi-party activity of religious fractions inside the ruling party and government. Without a serious analysis of the role of the state in Islamic countries, and without considering the relations between religion and state, it is impossible to understand how Islamic societies became so defenceless in the face of growing religious obscurantism and backward-looking political movements.

The third factor is the effect of imperialist policy during the Cold War. Throughout it, one of the major weapons of imperialist powers against liberation movements (and movements for freedom and socialism) in Islamic countries was religion. In using religion to stupefy the masses and to denounce opposition, imperialism was both resourceful and relentless. It used the religious weapon (through groups, parties and men of influence) to provoke splits in the working-class movement, sabotage progressive and nationalist movements, and even to destabilise anti-imperialist governments or those allied with Soviet Union.

An incomplete list might include the following. First, the assistance given to the rise of Ekhvane Muslemin (Muslim Brotherhood) against Nasser's regime in Egypt and the Ba'ath Party in Syria. Second, support for the Islamic Amal in Lebanon as a counterweight to the Palestine Liberation Organisation and progressive Lebanese leaders and parties. Third, the strengthening of the Fadaiyan-e Islam, and mullahs such as Ayatollah Kashani, in opposition to Dr Mossadegh's government and the Tudeh (Communist) Party in Iran. Fourth, the massacre of half a million communists in Indonesia. Fifth, the mobilisation of semi-military parties and organisations in Afghanistan and the provision of unlimited support to their efforts to overthrow the Marxist government. In so using religion, the imperialist intelligence networks may 
rely on facilities provided by countries such as Pakistan and Saudi Arabia, or on their own agents sent directly, to create or to infiltrate religious groupings or parties. Their support can take different forms, but the important point is that they played a central Cold War role in increasing Islamic religious influence in Islamic societies. We see the grave consequences today.

The fourth point is the effect of regional political crises on the overall growth of the pan-Islamist movement. The deadlock in Arab-Israeli relations in general - embracing the questions of Palestine; the occupation of Lebanese, Syrian and Jordanian land; and the persistence of military mobilisation and sporadic military confrontations - has aided the pan-Islamist movement. Nothing damages the standing of secular Arab nationalism more than the humiliation of Arab governments by Israel. The blind 'non-conciliatory' attitude of pan-Islamism when confronting 'Jews' seems well justified by the Camp David Accord and by other such retreats - the most recent of which is the creation of minuscule bantustans as a sop to Palestinian nationalism. Faced with the task of untying these religious knots, left and progressive forces have shown chronic weakness. This is the background to the way in which events such as the assassination of Sadat, the blowing up of US and French marine headquarters in Beirut, and, perhaps most critically, the Intifada itself, have become turning points. While the basic crisis remains unsolved, the pan-Islamist movement will continue to fill the political vacuum.

A fifth facilitating factor was the Iranian revolution of 1979. The coming to power of the first Islamic government to place pan-Islamism at the centre of its political and ideological agenda was crucial in the spread of 'political Islam.' Nor could the Iranian government remain even momentarily content with exercising indirect influences on the Islamist movements. From the beginning it did whatever it could to influence them directly and take over their leadership. All the Islamic movements were supported financially, logistically and by military training. Many groups and organisations were overhauled. Where necessary, the Iranian regime called on radical factions within Islamic organisations to split. It involved itself in an extensive organisation of terrorist and jihad-like cells, and embarked on an intensive drive to shape an Islamic international. Finally, it pursued an eight-year war with Iraq which was, above all, concerned with the 'export of the revolution' by military means.

The Islamic Republic of Iran is not alone today in 'exporting the pan-Islamist movement.' Other states, such as Saudi Arabia and Pakistan, are also actively making a bid to take over the leadership of the Islamist movement, to influence its policies and to spread religious illusions and superstitions.

Sixth, we must consider the effect of the collapse of the Soviet Union and, especially, the coming of Bush's 'New World Order', the after-effects of which will, for the foreseeable future, feed blind radicalism and militant 'anti-imperialist' - the Islamists prefer the term estekbar (loosely translated as 'arrogance') to 'imperialism.' In the conditions we have been outlining, legitimacy for pan-Islamist and similar movements comes when the prevailing gunboat diplomacy, and outright colonialist policies, of the USA and its allies, turns them into movements for gaining identity, prestige and pride.

In devastating the kindergartens and hospitals of Iraq, US and Allied planes lined up many millions of the downtrodden masses behind the Omar Abdel-Rahmans and Ali 
Belhajs of this world. The spokes people of world imperialism cannot claim innocence as they denounce the dangers of 'Islamic fundamentalism' and warn of 'fanaticism' endangering the security and stability of world civilisation. They know better than anyone that the global capitalist system has itself created the conditions for Islamic fundamentalism and fanaticism. They are the agents of another of history's ironic twists, through which the third industrial revolution has attached a backward-looking child to the maternal skirts of capitalism.

\section{How is society affected?}

The effect of all this is to grind away at the potential for class action, for democratic movements, and for cultural advance, as society becomes increasingly polarized and, at the bottom, destitute - as it faces grave psycho-social problems. From economy to politics, science and culture, wherever Pan-Islamism treads, it leaves a trail of conflict, contradiction and crisis. Its ruinous effects on secular life vary in extent and breadth at different stages of its development, and may at times even be self-negating, but there is a recognizable pattern to its development. We turn now to review this, first in conditions where the movement is in opposition, then when it gains political power.

\section{Political Islam in opposition}

Political Islam splits civil society at every level while leaving state structures intact.

In the first instance every type of class organisation, institution, political party, trade union and guild is split in half along confrontational religious lines. Islamic labour and peasant unions and guilds stand opposed to their non-Islamic equivalents. Nothing escapes this split, not even bourgeois class organisations and societies. Fissured into Islamic and non-Islamic categories, the sub-groups glare at each other across an ideological divide that causes major transformation in the social class line-up. New fundamentally non-class - blocs are formed. Labour-power lines up with either 'Islamic' and 'secular' capital under the umbrellas of 'Islam' and 'secularism.' Meanwhile, in society beyond the state, an embryonic form of Bonapartism emerges, offering an alternative future state formation. The potential for progressive class action is systematically eroded.

\section{Democratic erosion}

Simultaneously democratic structures and institutions are similarly split: the ideological weapon creates Muslim societies of doctors, lawyers, engineers, teachers, students, or women - distinct from non-Muslim groupings. The Muslim doctors can no longer defend their professional needs alongside non-Muslim doctors. Worse, their duty to combat atheism and blasphemy overtakes every other duty.

Civil society is fractured into the Islamic and non-Islamic: the divide rips apart everything from trade unions to professional organisations. This is the most profound and dangerous consequence of the pan-Islamic movement. It mobilises one section of society against another. This division even appears in some industries in core capitalist countries. The inevitable and tragic effect is to create artificial alliances throughout society, on the basis of sex, religion or ethnicity. Woman is set against woman, teacher against teacher, worker against worker. 
Where Muslim women organise separately from other women, not only do they enfeeble the women's movement in its struggle for democratic rights, they even compromise its ability to hang on to past achievements. We see the tragic sight of a woman who has lost all rights voluntarily saying 'yes' to her slavery. All this faces the democratic movement with its greatest dilemma. As its potential is eroded, a territory is created where the seeds of a future religious despotism are planted.

Paradoxically, the more the masses occupy the stage the greater the power of the leadership. Indeed there is an inverse relationship between representation and mass mobilisation. The leadership of these movements feed on mass activity. Their power becomes more concentrated and unassailable in direct relation to their ability to bring the masses on to the political scene. The appearance of the masses, in these circumstances, signals not the exercise of their collective will but rather their political disrobement. Where the masses are reduced to the umma (family of believers) of the iman - where, in its ideal form, they are the disciples of religious authorities (marja'a), then the more they make their presence felt in the political arena, the greater the authority of the leaders, imams and clergy. The role of an individual with his/her democratic rights in society, and the state, fades. The democratic base of society is weakened. The roots of future religious despotism are established and foundations of an ultra-centralized, leader-focused political structure are laid.

\section{Cultural fatigue}

In a society giving birth to a radical Islamic movement, the cultural make-up is the first victim. The cultural sphere disintegrates into numerous ever-smaller, conflicting formations, united only by belief in the absolute. This calamitous process effectively closes the route to cultural advance. Scientific thought, experimental sciences, philosophy, as well as values emanating from these, are walled off by absolutist cultural structures. The quest for the absolute - the struggle to annex knowledge to an integrated and dominant ideological monopoly - becomes the governing, social ethic.

In addition there is a return to the most extreme paternalism, superstition and machismo, deepening the roots of the ideas that will ultimately create, and secure, the ultra-conservative, absolutist, and despotic structures of the Islamic state. In this process, not only is the value-system of society overturned, but cultural, educational and ethical structures are overhauled. Muslim schools, Islamic social gatherings, and so on, reappear. The intellectual potential of society is gradually eroded. Thought, in all its manifestations is enslaved to belief and Islamic ethics. Sceptical questioning essential to scientific and philosophical thought - is rejected as a tool of the devil. Combine these pressures on independent thought with daily attacks on modernism and everything new, and the elements of a sterile and rigid intellectual life are all in place. Instead we have a situation in which intellectual servitude, demagoguery and obscurantism can breed; and in which religious despotism can grow.

\section{Social psychology}

More insidiously still, the psychological potential of society becomes poisoned, and with disastrous effects. A corrosive mixture of absolutism and power-worship, juxtaposed with the placing of a monopoly belief at the centre of the social valuesystem of a polarized society leads to a cult of violence. The ideological process numbs 
the senses, creating an acceptance of a militaristic, police mentality. This can be expressed as the exhortation to the violence of the jihad (holy war); as the amre be ma'aruf (or duty to punish those who do not observe Islamic laws); as the cult of martyrdom and the 'blood' (witness the fountain spewing blood in the 'Martyrs' Cemetery' in Teheran); and as the self-mutilation associated with the mourning of saints and martyrs. All these, and other things, create an atmosphere where acts of violence and the shedding of blood become a social norm.

It is in this context that the deliberate burning of the Rex Cinema in Abadan by Muslim revolutionaries, which cost 600 people their lives, should be seen. Later, came the immolation of over thirty Turkish secular intellectuals in Sivas, and the knifing to death of Croatian workers in Algeria. A culture is being created based on hatred of 'other' human beings. A mentality of mistrust, fear, tension, and friction permeates society's every cell. Hand in hand with this goes the culture of spying and prying into the life of others at home, work, school and college. One section of society spends huge amounts of time and energy reporting the 'misdeeds' of the other. The corruption of family, human, professional and other relations cannot be underestimated. It is indeed ironic that a religion dedicated to making the family the pillar of society rips family ties asunder by getting one member to interfere with, even spy on, another. A culture is built on treachery.

There are other negative outcomes. The situation increases the power of the male, the khan, and the mullah; leads to unquestioning acceptance of received wisdom; encourages crude populism; promotes the reduction of difficult concepts to simple absurdity; and creates fertile ground for the rise in religiosity and belief in the supernatural. Ultimately this leaves social mistrust and creates the basis for future ideological and police-military repressive institutions.

\section{In power: the political sphere}

Once pan-Islamism creates a state in which religion rules, its effect on the environment is immeasurably greater and longer-lasting. Some of these effects will undoubtedly survive long after the Islamic regimes return to the grave from which they rose.

As we have seen the roots of what becomes the Islamic State are established before political Islam comes to power. Fundamental changes in polarising society differently in class politics, in cultural and intellectual life, in social psychology and in the system of social ethics - have already taken place. Ideological and political values that have stubbornly survived for centuries are now co-opted into service. What we now see is, in effect, an overwhelming tendency towards the abolition of the modern state - to the extent that its main indicator, its secular superstructure (the separation of politics and ideology, especially religious ideology) comes under siege.

Sharia'a law displaces secular law. A system of law based on the parliamentary vote, rationality and contemporary human needs is replaced by one held to be sacred and eternal. A process is unleashed to overturn the general structures of political power, giving the ideological institutions pivotal positions in the exercise of that power. The traditional role of the state is overturned, and it is transformed from the mechanism for the control of the country's socio-economic tensions into the cause and perpetuator of those tensions and social crises. The contradiction between a religious-ideological state and its secular, material, rational base creates a situation of permanent crisis. A 
religious despotism is established in which the ruling Islamic power creates a new legal system, where the right to govern at every level (legislative and judicial) is held to be divine - exercised solely on god's behalf by certain sections of the clergy. The modern capitalist state's formal equality of citizens before the law is abolished. It is replaced by a legal system where the 'government of the ruling Ayatollahs' stands above, and in authority over, the masses.

\section{In power: the enlarged and interventionist state structure}

Three aspects of this greatly enlarged and more interventionist state structure must be examined.

First, what in effect happens is that civil society is more or less abolished. One part of it is absorbed into the state itself, while the rest disappears. Underlying this process is the denial of the independence of the private from the public sphere. Islamic government recognises no such boundaries. No part of life is considered private and outside the control of divine rule, and that of god's representatives. This totalising conception underlies the need to bring the very concept of civil society to an end. The sector reconstituted accepting the ruling ideology is organically incorporated into the state. The sectors that persist in their secular existence are annulled.

Civilians are mobilised in readily available gangs to attack bookshops or dissident groups - the 'mobilisation of the dispossessed' (basij mostaz'afin), involving millions. Islamic societies are set up and Islamic Shoras (committees) of - for example - workers, craftsmen, tradesmen, commercial people, are created around mosques, Hosseiniehs, the institutions of Friday Prayer, etc. All this allows the Islamic state to spread its tentacles into every home.

It is a rare trade organisation, cultural grouping or political gathering that can escape this fate. The paradox of complete absorption or total abolition is enacted with increasing determination and force, the deeper the ruling Islamic regime digs in. Ultimately even those institutions to some extent independent of parties, trade unions, etc., are abolished, or at least transformed into appendages of the police-security apparatus, or of the management of the office or enterprise. The remnants of civil society, in short, are militarised - or vaticanised - playing their role for the state in policing or ideological control.

This process encourages a ballooning of bureaucracy; reduced productivity; obstructionism; the multiplication of centres of power and of parallel institutions; and corruption, bribery and nepotism. While state bureaucracy is greatly expanded, its power is paradoxically eroded. The greater the power of the state, the more 'private' that state becomes. Not only is the modern state abolished, the state that replaces it becomes the representative not of the general interests of capital, but rather of the particular interests of specific capitals.

The second phenomenon consequent on the new state structures is the depoliticisation of the masses. Pan-Islamism in power politicises the whole of society and maintains it in a state of constant mobilisation. One section of society imposes state control, the other opposes by whatever means it can. Society is driven in two opposing camps: the religious and the secular. Paradoxically, however, this permanent politicisation tends to create its own opposite - through exhaustion comes depoliticisation. Once 
depoliticisation spreads to both camps in a society with an atomised class formation and political base, the longer term potential for change and progress towards democracy is seriously weakened. The future for these societies is truly dark.

The third point to be commented on concerns the inequality of citizens before the law. The equality of citizens forms the legal basis of the modern state. This too is negated in Islamic societies where the interference of ideology creates several legal layers in society - for example, there are separate inheritance laws for men and for women; for Muslims and for non-Muslims. Radical Islam creates citizens equal when it comes to obeying laws but not when it comes to changing them. Man cannot reject laws that have been divinely ordained (and as they have been interpreted by the mujtahed - the learned mullah).

\section{In power: the economy}

Perhaps more than in any other field, the rise to power of the pan-Islamist movement brings the societies it governs into conflict their own material infrastructure. If the main role of the state in all societies, including Islamic peripheral countries, should be to 'recreate the external conditions for production', the 'Pan-Islamist state' in practice tends towards multi-dimensional and permanent economic crisis. In particular, the ideological Islamic state cannot use to the full the various levers with which most states regulate the economy - the law, money and force.

To look at all three in turn. Ideology weakens the use of the law, one of the most important interventionist tools in the hands of the state. The law's rational, objective elements become overshadowed by ideological and political considerations. As a result, the secular and 'rational' economic sphere constantly finds itself in opposition to (essentially ideological and irrational) law, and slips out of the latter's control.

Ideology limits and obstructs the workings of the laws of capitalism too, including its fundamental law of value. The equality of a commodity in exchange is eclipsed by its inequality in ideology: the law of value is constrained or made conditional. Hand in hand with this limitation goes a certain liberalism. Ownership is valid so long as religious tax is paid and it has been obtained by 'legitimate' (mashrou') means. An ideological element thus enters both into ownership and into the exchange of property. A property used for un-Islamic purposes (e.g., brewing) or for which religious tax has not been paid is illegitimate and cannot be exchanged. Commerce is also affected by ideology (some commodities, such as alcohol, 'immoral' literature or films, videos, many articles of clothing, etc, cannot be bought or sold).

On the question of money. This vital lever of state intervention in the economy faces a similar fate. Money essentially loses its function to fulfil the needs of production and circulation. Instead, the religious-ideological state uses money to answer its political and ideological needs. The volume of money in circulation is allowed to expand at an uncontrolled rate - dictated by political considerations. Consequently the money supply is no longer a stabilising but an anarchic element in the economy. This process allows huge quantities of money to accumulate in a few private hands, creating equity that then confronts the state, vitiating its control, and even determining its actions. As in the case of the law, money is used to offset the contradictions between the ideological state and its material-economic base; and in the process comes to function 
as its own antithesis - destabilising rather than stabilising the economy.

As to the use of force, its function in a Radical Islamic government as a purely repressive tool is even more obvious in the economic sphere than in others. Force is not deployed as it is in a 'normal' capitalist state - to suppress the conflicts and contradictions between the various sectors of the economy, and to paper over cracks so that conditions for the reproduction of capital are optimized. Instead, it is used to suppress the conflicts and contradictions between the economy as a whole and the ruling political power. The use of force, whether material or ideological - that is whether taking the form of expropriation, legal suspension, fines, imprisonment, etc, or of denunciation as diabolic and un-Islamic from the pulpit - has one consequence: it creates massive insecurity in the economic realm.

The result is the creation of a complex web of non-economic structures, entwined with a parasitic and unaccountable structure of capital. A powerful defensive perimeter is then built around this alliance protecting it against both the ideological-material coercion of the state and against blind economic forces. This huge mafia-like structure has, at one extremity, the 'bazaar' and the mosques, and, at the other, the armed forces and the religious courts. Such is the inevitable fate of societies unfortunate enough to live under a pan-Islamist regime.

There are further effects of pan-Islamic rule on the economy, which go beyond its enfeebling the state and which have even more direct effects on the potential of these societies for economic development. We need to look at investment, human resources, the labour code, and science and technology.

In these societies, both internal and external capital fights shy of investment in long-term projects. Domestic investment is discouraged by the fall in the rate of capital accumulation. One factor in this is the expansion of an interfering, totalitarian and highly expensive state. A huge burden is placed on the gross domestic product and value-adding activities, which hinders the possibilities of capital accumulation in line with developmental needs. The impact on the state sector is decisive and disastrous.

The effect on the private sector is less, but considerable, leading it essentially to shun investment in productive industries. It is affected by the prevailing insecurity brought about by the ideological-political policies we have discussed. Instead, capital is drawn into quick-return transactions. It also tends towards less accountable areas. All this means that the private sector, prompted both by the most efficient pursuit of profit and by non-economic considerations, tends to eschew productive investment in favour of playing the stock market, hoarding, speculation, buying and selling, real estate and land transactions, and so on.

Meanwhile, general economic conditions mean that the ability of the state sector to invest in vital parts of the economy is also progressively eroded. Sectors of the economy dependent - because of low profitability or poor development - on state investment therefore also fare badly. Increasing inequalities and imbalance is caused in an economy already suffering the uneven development of a peripheral capitalist economy.

Foreign sources of investment are even less likely to respond. In addition to the economic factors we have discussed are political factors, amongst them an insecure 
legal-judicial atmosphere, and Radical Islam's adventurist foreign policy. And there is a further element: the deliberate use of the economic weapon, including official sanctions, by core capitalist countries to control crisis-provoking Islamic governments acts as 'a barrier to the entry of international finance into these countries. Where investment does take place, it is highly calculated and of a politico-economic nature. Thus Japan and Italy have tried to ensure their future supplies of oil in Iran by investing in petrochemicals or other strategic goods. But even here, where they are securing their supplies against present and future rivals, advance payment has been extracted in the form of oil sales, itself fulfilling the need to secure oil stockpiles.

On human resources: this most vital of all factors in economic development is also exhausted under Radical Islamic governments. The productivity of manpower under capitalism is intricately linked with skill levels, education, research, etc. A secular, scientific and experimental environment encourages their development which in turn serves to refresh that environment. But the Islamic government crushes this through the pressure it brings to bear on secular life (including schools, universities, scientific and research centres). The regime confronts science with belief (maktab). Its ceaseless interference in secular life even forces many of those who already have skills to flee the country or to abandon productive economic activity. The Islamic state thus not only fails to recreate a qualitatively advanced workforce, but deskills the existing labour force, hampering the ability of the economy to expand. Nor does this environment attract foreign workers of sufficient calibre, who also have to cope with limitations on foreign exchange.

In Islam it is not the function of the state to regulate labour through a labour code. The usual legal framework designed to deliver a labour force that is not unduly worn out is thus absent. The equal exchange of labour power is replaced by the law of 'rental' of labour where the contract is between the individual and the owner without regulatory intervention. Where a labour code has been legislated, as in Iran in 1992, it has been under intense pressure from workers, and after great procrastination.

Science and technology is an essential ingredient of economic development, but, in radical Islam, this too succumbs to the blows of ideological control, especially at the university and technical college level. The return to the amalgamation of religion and the state prevents the flowering of science. The potential for domestic technological development is at best confined to selected areas. Foreign technology is also largely inaccessible for political and foreign-exchange reasons. Moreover, the absence of a sufficiently advanced domestic technical skills-base limits the potential benefits of imported technology. So the result is to deny society one more key lever for economic development.

In short, Pan-Islamism in power is ruinous for the economy. Though retaining capitalism as the dominant mode of production, capitalist development is slowed down in certain fields without being able to resurrect some pre-capitalist forms of production. Thus the inherited multi-structured economy (containing elements of pre-capitalist economy in the midst of a dominant capitalist economy) is faced both with paralysing contradictions and internal anarchy; and with the existent unequal development of international capitalism, now accentuated to breaking point. The peripheral economy, as it comes under Islamic rule, cannot escape the additional disruption involved in its now-fractured relationship to the core countries - a 
relationship crucial for the external reproduction of capital that is so vital for such an economy. The net result is to push the economy into reverse; wear down the superstructure and infrastructure of the economy; dry up the economic resources and future potential; and finally mortgage not only the present but also the prospects for a recovery. Pan-Islamism in power creates the conditions for the Islamic societies to sink in a sea of poverty and destitution.

\section{In power: culture, social psychology and social atomization}

In the sphere of social psychology, all those elements in Radical Islam that, before achieves power, have already begun to transform the system of values, the intellectual structures, and the cultural face of society now come into their own. The two opposing cultural camps, each reacting to the other and rapidly moving towards the extreme in their positions, define themselves as the negation of the other. Each camp - the Pan-Islamist counterposed to those against Radical Islam, the religious against the irreligious or even anti-religious - creates its own separate systems based on absolute values.

Anyone not a fervent believer in Radical Islam is a heathen and a devil. Conversely, any Muslim is a murderer, oppressor, plotter, etc. While one camp looks on the exposure of a few strands of a woman's hair as prostitution, the other denounces any attempt at defining morals in private and sexual life as fanaticism and backwardness. In practice, this process manifests itself as a strange whirlpool of false pretensions to religiosity, institutionalised hypocrisy, nihilism and immorality, pulling equally in opposite directions.

A further feature of this tragic cultural transformation is the way it acquires a repressive police function. The culture of Radical Islam, in becoming the official culture, is absorbed into the political structures of the state. Non-Islamist culture enters the realm of the forbidden as a 'anti-culture', a 'cultural enemy', a 'cultural danger' and 'cultural corruption.' It is unceremoniously removed to the realm of the forbidden. Both cultural trends - the Pan-Islamic and its counterpoint - become completely subordinate to ideology in a process that follows an almost inevitable path towards an atomised society.

The faster the official culture takes shape, the more it is equipped with repressive tools. The greater is the absorption of ideological structures into the state, the greater is their control of cultural life. The more education becomes part of the ruling religion, the faster the news media become schools of indoctrination, entirely lacking in diversity. In short, secular life comes under increasing ideological control and greater pressure. And the opposite is true too. Social opposition, reactions of discontent, criticism take the form of 'cultural attack' and 'cultural confrontation.' Culture becomes totally politicised.

In the absence of a political opposition with any influence, popular protest is either explosive (this is the usual form it takes) or it manifests itself in an individual and atomised cultural form. There develops both an open and an underground war over everyday-life issues. There are major conflicts in which, using primitive weapons, opponents of the ruling culture mock its many manifestations - the dress code, the 'pagan' national festivals that provoke street battles, the duality of home and public life and morality. Scratch the surface of a Radical Islamic society and you will witness its 
antithesis deeply permeating its every aspect. The irony is that Radical Islam, which emerged as a movement for 'cultural revolution', finds itself surrounded by a 'countercultural revolution.' History mocks the very imams who are the epitome of absolute power by having them humiliated in running battles with rebellious 'youth.' The ruling mullahs are forced to admit that the cultural assault by the 'enemy' (read: the young who have known nothing but the Islamic regime) is the greatest danger they and the 'Islamic revolution' face.

\section{Opposition atomised: the challenge for the left}

But there is a danger signal here for progressive forces too. This backward turn in the social struggle, from one which is conscious, and organised on political lines, into an atomised, individual, absolutist, cultural battle, without clear class aims and lacking any real political consciousness, simultaneously wears down the cultural potential of Islamic societies and drains them of political health. The sad reality is that even when the religious-Islamist governments are overthrown, the future looks bleak. What progressive and stable socio-political system can take root in a society mired in uneven development, polarized and depoliticised, where public discourse is populist or demagogic? Social and moral indifference, negativism and nihilism, hypocrisy and pretensions to religiosity, rule. Paternalism is in command and the dominant relationship in society is that between the follower and the followed, the disciple and the mujtahid (religious authority). Such societies have sunk into a lumpen, get-richat-all-costs mentality, glorifying both money and violence, aggressive towards the weak yet simultaneously characterized by sycophancy and opportunism.

How can a society which has fallen victim to pan-Islamism throw off this massive dead weight of cultural psychological trauma? What is to be done? Our purpose here is to issue an invitation - for a dialogue over one of the most vexed questions of our time. What are we to do about a blind and reactionary revolt of the downtrodden?

A child of our time and a product of the ruinous effects of advanced capitalism in Islamic societies of the periphery, Radical Islam confronts the left with its most difficult challenge: how to respond to a reactionary, grass-roots movement, arising out of desperation - a movement which destroys class, cultural and even psycho-social potential, leaving society disarmed and ill-equipped meaningfully to confront its own ruinous state. The actual response of the left has not so far been edifying. Both in the region, and at a global level, it is paralysed by a phenomenon that presents a contradictory challenge to its instincts.

Here is a movement with claims to a mythical past, but born 'out of time'; a movement promising to lift millions into a just future based on that illusionary past. It is born into a present characterised by increasing polarisation of wealth and poverty, of development and backwardness, which consigns millions to the rubbish heap in advanced capitalism's backyard. At one level the movement consists of the most downtrodden in society, crying out for their rightful share; on another, it tramples on those very structures and social formations with the potential for progressive change. On the one hand, this movement espouses anti-imperialist slogans, on the other, it destroys the class which can truly organise to overturn imperialist domination. It saves the capitalist mode of production from the onslaught of those who want to tear down its ramparts, but at the same time it disrupts capitalist accumulation and provokes the 
wrath of global capital. It mobilises huge numbers around the slogans of 'equality of the Islamic umma' (community) and an end to hunger, and yet its policies drive society into ever greater unequal development, poverty and social polarisation. It calls for 'independence', and sacrifices all political freedoms. It calls for 'freedom.' and enslaves the female half of the population - not to mention minorities and all those who think differently. In the name of the right to cultural independence it discards universal rights and justifies despotism, forcing a grey uniformity on millions. In the name of participatory democracy it makes millions assent to the increase of absolutist power over them - seemingly giving a willing 'yea' to slavery. People are increasingly mobilised and politicised only to end up being pulversied into individual units expressing their opposition in a depoliticised culture of negativistic rejection; and a movement that declared itself the anti-corruption movement to end all such movements itself weaves corruption into the very fabric of society.

There have been two basic reactions to Radical Islam, the first a policy of political alliance; the second one of confrontation, with the aim of bringing about its ultimate destruction. With the end of the Cold War, the first response - from the point of view of the left - has faded. But at its height both left and right followed the hallowed doctrine of 'uniting against the common enemy.' Radical Islam was both anti-capitalist and it was anti-communist, so at no stage was it short of potential allies - whether from the Soviet bloc with its blind 'anti-imperialism'; or from the imperialist countries, with their virulent anti-communism. On the left there were different attitudes to the potential alliance. Believers in the 'non-capitalist road to socialism', for example, saw it as strategic and unconditional; for others it was tactical, dependent in the longer term on the attainment of proletarian hegemony within the revolution. But there were also perceived advantages in an alliance for capitalism, which was itself instrumental (directly and through client states) in bringing anti-communist Islam into being and encouraging its growth as part of its policy to contain the working-class movement. The methodology of both left and right has been identical: you identify your opposite anti-imperialism for some, anti-communism for others - and ally with its opposite. For the left, it is important to recognize, however belatedly, that this method never had much to with Marxism. It was, rather, a product of Stalinist distortions - vulgarised further in the light of the revolutionary peasant movement in China.

\section{After the Cold War}

When the end of the Cold War took one bloc out of the equation, both right and left turned to a policy of confrontation. In general terms, two main trends can be discerned in the way the surviving (capitalist) bloc, and its allies, faced Radical Islam. The first was to liquidate it ideologically; the second to combine pressure and threats with appeasement and aid to force it on to a path of 'reform.' Neither was new. Both had, for example, been practised by the builders of the modern state in Islamic countries earlier in the century - by Ataturk in Turkey, by Reza Shah in Iran, by Bourghiba in Tunisia, in post-war Syria, and even in Pakistan (ostensibly an 'Islamic state'), and so on. What is new is the vigour with which, and the scale on which, these policies are being pursued today.

Modernisation and the formation of the modern state in the countries listed above involved, above all, a process where social institutions and values had to be secularised; where rationalism replaced hadith (actions or sayings of the Prophet and 
the imams) and where laws that can be changed replace immutable divine law (sharia'a). Those hoping to reform Radical Islam argue that pan-Islamism is a cultural movement, and a reaction to the formation of the modern state. These states overturned social structures too rapidly, provoking a blind and angry reaction. As these people were unabsorbed in the modern state their political reaction against that state has taken a religious form.

Those who argue thus remind the proponents of the policy of the whip that belief cannot be suppressed through repression. The answer, accordingly, is to put a brake on change, and introduce certain reforms favouring religion, while retaining the overall framework of the modern state. The ploy is to change the ruling bloc in such a way as to broaden the social base of the regime. An alliance is sought with one section of religion against another. The resulting political stability is thought to weaken the appeal of Radical Islam, and marginalising it in the political equation. It is vital, however, to keep the new Islamic allies away from the key centres of power (the army, the security apparatus, etc.). Examples where such policies have been put into practice are Jordan, Yemen, Pakistan and, earlier, Egypt.

A variant of this policy is proposed for those countries where neither the prospects of a coalition government exist, nor is the secular state viable. This is to abandon the quest for modernisation and leave the task of amalgamating the national capital with global capital - that is the task of reconciling the capitalist infrastructure with aspects of religious culture - in the hands of reformist Islam. The aim is to stabilise the political structure of society while avoiding the dangers of outright modernisation. Unlike the first proposition, which holds that the rigidity of sharia'a cannot cope with the changing needs of a modern state, this one believes that religion and capitalism can be reconciled. The argument between these two interpretations is ongoing.

The two views share a common core. They rely on Islamic reformists to secure the interests of the West - in the one argument as a junior partner to secularists; in the other, in their own right. The task of making the political and economic structures of capitalism compatible with indigenous culture (in a country of the periphery) is, in both cases, given over to reformist Islam - though it is understood that some outside pressure must be brought to bear on religious thought to force it to seek accommodation with secularism and take the road to transformation. Needless to say neither policy ever operates in its pure form. Specific conditions impose some degree of compromise between the different roads (in Algeria or Egypt, for example), resulting in highly complex policies, and, in some cases, repeated U-turns.

\section{Wrong analysis, doomed policies}

Such policies are all likely to fail, in the main because they do not address the root cause of Radical Islam. The movement is not a reaction against the modern state. It is a product of the effects of the modern state in a peripheral country in globalised, late capitalism.

The reformers who see the pan-Islamist movement as a cultural phenomenon, a reaction to the formation of the modern state and the over-hasty destruction of traditional structures, are on slippery ground. They mistake cause for effect and cannot explain why this 'reaction' occurred in the 1980s - in some of the countries involved over half a century after the modern state was established. Nor can they 
understand the explosion taking place today, when, thirty years ago, Radical Islam was effortlessly crushed by Nasserism.

Our argument is that Radical Islam is a reaction to the effects of particular forms of modernisation, not to modernisation per se. This is not a trivial difference. For one thing, understanding it profoundly affects the strategies needed (and discussed below) to overcome political Islam. The idea that its successes simply represent a social reaction to secularisation ignores the fact that virtually all these societies are multicultural formations, in which advanced capitalism exists precariously alongside pre-capitalist and even tribal structures. Sizeable sections of society are not at all averse to modernisation. Theories dependent on the idea that Islamic countries are simply backward ignore this complex cultural reality. Moreover, examples of the failure of the policy of accommodation abound. Appeasement has not diminished the spectre of Radical Islam in Pakistan. Saudi Arabia fed and helped create Hamas and FIS to counter radicalism, only to find they have become a radical threat to their sponsors. The appeasement strategy is doomed in practice, just as it can be shown to be mistaken in theory.

\section{The Iranian left}

According to sections of the Iranian left, faithful to a highly formalistic, deeply rooted economism and a crude statism, any government that increased state ownership at home, and sided with the so-called 'socialist bloc' abroad, was a natural ally of the world proletariat, regardless of the degree of participatory democracy it permitted or the relations of production it established. State ownership was even identified as the criterion for 'socialist' transformation.

An alternative view, more recently in vogue, rightly rejects such statist economism, but only to replace it by another one-sided view, this time immersed in a cultural interpretation. Culture and ideology are considered the essential elements of Radical Islam, and also the route to its negation. One such interpretation combs the past in search of anti-orthodox-religious elements in national culture. One favoured source is Islamic mysticism, but there are also pre-Islamic movements, such as Manichaeism and Mazdakism. Egalitarian and humanistic elements in mysticism are brought in to confront official organised religion, and to create an alternative to it.

In contrast, there are those who declare that there is nothing in national culture on which to build. This argument, made by many prominent thinkers of the 'new left', claims that democracy will never take root in Iran and similar societies unless cultural backwardness can be confronted. Total secularism and modernism is their solution for a free and democratic society and economic growth. Such concepts as mystical 'love' and 'self-sacrifice' are seen as a total negation of nature: they cannot be the buildingblocks of a socialist future. 'Love' is inseparable from the love of god, they argue, and at its core lies a death-worship. Such thinkers advocate a total rejection of national culture and union with world culture.

These are both intellectual movements seeing culture as central and defining the task as the creation of a new one. The latter group claims to follow Heidegger - but they are not particularly faithful to him, since they propose to build a new culture from scratch, rejecting all existing culture. The effect of such a strategy is to separate the intellectual completely from society. And, despite their claim to articulate a radical left 
solution, they echo the liberal cry that it is not possible to have democracy, or take steps towards socialism, in societies on the periphery of world capitalism, especially in countries where a tradition based on religion exists.

\section{The international Left}

Interestingly the positions taken by the left outside Iran have similar overtones. A few diehards continue to cling to the economist view that 'the enemy of my enemy is my friend.' This was most clearly demonstrated in the position taken by some on the Mujahedin in Afghanistan, and during the Second Gulf War. The folly of this philosophy was best illustrated by the way all but an unrepentant few have now had to eat their words about this policy as they applied it to Iran. Others take a pragmatic line, seeing their alliance with pan-Islamism as tactical and temporary. They argue that it is important to unite against imperialism at this juncture, and deal with future rifts as and when they arise. Most of those who took this ostrich-like view in Iran are, unfortunately, no longer in this world to see the folly of their ways. Those (particularly in the Palestinian movement) who think they might work this strategy more successfully (and less fatally to themselves) should remember the innate enmity of Radical Islam - itself a brittle coalition of antagonistic class interests - towards any ideology that looks at the world through class spectacles. The third view is even more pernicious. It wraps its intensely racist theories in seemingly libertarian words. Let each people follow its own cultural norms, it holds. By rejecting universal human rights this view is, at best, a form of vulgar populism and, at worse, dangerously racist, confining large tracts of humanity to permanent exclusion from rights enjoyed (as rights) by others. Not surprisingly they found themselves, at the 1993 Vienna UN Conference on Human Rights, sharing a platform with some our planet's most vicious regimes.

We have argued, then, that Radical Islam is of our time - a child born not 'out of time' but rather out of today's profound economic, political and ideological crisis. In relation to this, the 'cultural' crisis is not so much a cause as a blindly reactionary effect. Radical Islam is not a response to the modern state, modern culture or the separation of the religion and state, but rather to mass unemployment, destitution and hopelessness brought about by the modern state. It is not so much a reaction to the essence of modernism but to the ravages of advanced capitalism in a part of its periphery. Those thrown on to the rubbish heap of history claw at the nearest available ideology at a time when liberalism, nationalism and known forms of socialism are all sinking in a quagmire. The past rules the present in those societies not because of its robustness, but more because of the feebleness of the alternatives.

It is, therefore, futile to imagine that any project that does not offer a fundamental solution to the political and economic crisis can forestall the genesis and growth of such blind and ultimately destructive movements. It is also clear that any political solution must be accompanied by a cultural renaissance congenial to human feeling, intellect and thought. This requires nothing less than a full-scale ideological springcleaning for the left. The three major planks on which the left must confront the pan-Islamist movement are: first, the formulation of an independent and radical economic programme; second the development of a coherent political platform; and third, a thorough overhaul of its own system of beliefs and ideas about organisation.

\section{A radical economic alternative to neo-liberalism}


Where advanced capitalism is polarising the world into extremes of affluence and poverty that now transcend geographical boundaries, one cannot talk of an independent economic programme that does not challenge neo-liberalism at every level. This means confronting the so-called structural adjustment policies of the International Monetary Fund and the World Bank, which are bringing about the destitution of millions in the North as well as in the South. It is on this ground that the left must distinguish itself from the liberals who also seek to woo the masses breaking away from Radical Islam. In the South this means a number of things.

First, key sections of the economy need to be in public control, which is not necessarily the same as state control. It has to be promoted as the most suitable form within which the labour force can be directly involved in production, with a major input into meaningful decision-making. Second, the producers must control the means of production not just in legal terms (such as an article in the constitution) but in real political and practical terms. Third, the right balance must be created between central planning (without which it would be impossible to overcome the inequalities) and decentralised workers control. Fourth, the system of social security must improve the quality of life - something that cannot be achieved without the working population controlling state expenditure, in particular with regard to welfare, subsidies and wages.

These, and other similar, economic policies are crucial if the left is to unite with, and mobilize its main social base - the downtrodden. Only with a radical programme addressing the root cause of mass destitution, confronting the core-periphery contradictions, and showing how to overcome uneven development, can the left attract its natural class allies away from the clutches of Islamic obscurantism.

\section{Clearing out ideological baggage on the left: alliances and cultural heritage}

As we argued in part one of this essay, the Islamic movement filled a vacuum created by the ideological feebleness of the two main social classes - the native bourgeoisie and the young working class. But we must also confront the fact that the left, as it exists in these countries today, is singularly ill equipped to lead the implementation of the programme outlined above. A major rethink is necessary if the left is to fill this ideological vacuum before those who would promote bourgeois alternatives have produced new prescriptions with their already sharpened pens. Without such a rethink the left can entertain no hope of truly representing the interests of workers, organising working-class struggles, and becoming integral to a genuinely mass force in those societies. Two aspects of this need particularly urgent reappraisal, the first relating to alliances, the second to the cultural inheritance of the left.

It is time the left returned to a class-based analysis of historical development, too often ignored in the recent past. It must make all alliances with political forces and organisations conditional on the true class interest of the working class it claims to represent. For too long it has made the most incredible contortions to justify its support and alliance with a variety of unsavoury groups. A crude anti-imperialism, devoid of any class analysis, fed at times by the totally discredited theories of 'non capitalist road to socialism' have underlined these justifications. The support given to the Islamic Republic (a regime which systematically and brutally destroyed all the working-class and democratic organisations and structures that grew out of an anti-capitalist revolution) was, in some places, given out of sheer pragmatism or even 
opportunism; in others, from a genuine but misguided anti-imperialism.

The left has to wake up to the fact that in the interface between the ravages of advanced capitalism in the South (and also the North) and the weakness of the working-class alternatives (organisationally and ideologically) a whole series of movements and insurrections will arise with 'radical' and even 'anti-capitalist' content. The left of today and tomorrow faces movements, often from below, fuelled by desperation, and containing a bewildering intermix of progressive and reactionary elements. To steer a course of solidarity and alliance in this morass requires a clear vision of the left's future, based on a clear understanding of where the interests of the working class lie. The experience of the Iranian revolution, and of other major twentieth-century revolutions, clearly points to the fact that all alliances and solidarity must be subordinated to one consideration only: does the policy serve the true interests of the working class?

Without a thorough reappraisal of its cultural and intellectual heritage the left will remain marginalised in the huge battles ahead. The ideological vacuum will be filled by various bourgeois alternatives: liberal here, totalitarian and fascistic there. The left, on both sides of the North/South divide has a long way to go. Meanwhile, the cultural and human ravages of advanced capitalism will continue to be met by the opposite but equally appalling ravages wrought in the name of false utopias, generated from the turbulent depths of the despair of the 'wretched of the earth.' 